\title{
КУЛЬТУРНО-ДОСУГОВАЯ СФЕРА ПОВСЕДНЕВНОЙ ЖИЗНИ КРАСНОЯРЦЕВ В 193О-е ГГ. ХХ В.
}

\author{
N.V. Voroshilova, A.V. Tolmacheva, \\ U.A. Guyvanskaya
}

\section{CULTURAL AND LEISURE SPHERE OF EVERYDAY LIFE OF KRASNOYARSK CITIZEN IN THE 1930-S OF XX CENTURY}

Рассматривается эволюция форм культурно-досуговой деятельности населения города Красноярска в 193о-е г2. ХХ в. как результат воздействия государственной политики в этой сфере, изменения культурных потребностей самих жителей города, а также условий их удовлетворения. В 193о-е г2. произошли существенные сдвиги в культурно-досуговой сфере повседневной жизни населения города Красноярска. Прежде всего, возросли возможности для более разнообразного и насыщенного досуга красноярцев благодаря расширению сети культурно-просветительских, культурно-зрелищньх учреждений, мест организованного отдыха населения, появлению и расширению радиовещания. В структуре досуга жителей Красноярска возросла роль чтения книг и печатных периодических изданий, посещения кино и театров, прослушивания радиопередач, а также активных досуговых форм - художественной и технической самодеятельности, спорта, туризма. В годы форсированного построения социализма активизировалась политика советского государства по вовлечению населения в официальные, коллективные формы досуга, являвшиеся средством идеологического воздействия на общество, и сужению возможностей для неофициальных, традиционных его форм. Особый акцент делался на антирелигиозной пропаганде и борьбе с различными проявлениями девиантного поведения. Серъезными факторами изменений стал также рост грамотности и образованности и уровня жизни населения. В результате в повседневной жизни красноярцев в зо-е г2. постепенно утверждались новые формы досуга, но до конца они не смогли вытеснить традиционные, патриархальные способы препровождения свободного времени, чему способствовал массовый приток в город сельских жителей.

Ключевъе слова: повседневность, досуг, формы досуга, официальные формы досуга, традиционные формы досуга, художественная самодеятельность, активный отдых, пассивный отдых, культурнозрелищные учреждения. 
The evolution of the forms of cultural and leisure activity of the population of the city of Krasnoyarsk in the 1930-s of XX century as a result of the influence of state policy in this sphere, the changes of cultural needs of the residents, and also the conditions of their satisfaction was considered. In the 1930-s there were essential shifts in cultural and leisure sphere of everyday life of the population of the city of Krasnoyarsk. First of all, the opportunities for more various and saturated leisure of Krasnoyarsk citizens thanks to the expansion of the network of cultural and educational, cultural and spectacular establishments, the places of organized rest of the population, the emergence and expansion of broadcasting increased. The role of reading books and periodicals, visiting the cinema and theaters, listening in as well active leisure forms - amateur and technical performances, sport, tourism increased in the structure of leisure of the residents of Krasnoyarsk. In the years of forced building of socialism the policy of Soviet state on the involvement of the population in official, collective forms of leisure which were the means of ideological impact on the society became more active, and resulted in narrowing the opportunities for informal, traditional forms. Particular emphasis was placed on antireligious propaganda and the fight against various manifestations of deviant behavior. The growth of literacy and education and the standard of living of the population also became serious factors of changes. As a result in everyday life of Krasnoyarsk citizens in the 1930-s new forms of leisure were gradually approved, however, they were not able of complete replacing traditional, patriarchal ways of spending free time. This was facilitated by the massive influx of rural residents to the city.

Keywords: everyday life, leisure, leisure, official forms of leisure, traditional forms of leisure, amateur art, active recreation, passive recreation, cultural and entertainment institutions.

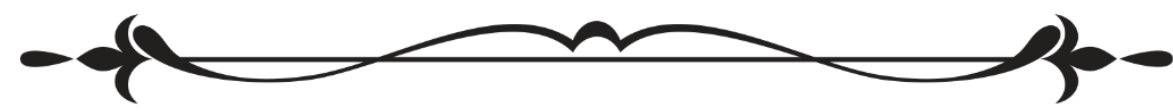

В советской историографии история повседневности относилась к малоизученным сюжетам. Значительно больше внимания советские историки уделяли вопросам жизни и быта граждан, выступавшим в качестве иллюстраций успехов социалистического строительства. Хотя эти труды содержат немало фактического материала, в том числе о новых формах досуга и быта граждан СССР [1]. Между тем в зарубежной науке феномен повседневности находился в центре внимания представителей различных наук на протяжении многих десятилетий (так, различным аспектам советской повседневности 1930-х гг. посвящены работы Ш. Фитцпатрик и М. Рольфа [2, 3]), и с 1990-х гг. в его изучение активно включились отечественные исследователи. В огромном комплексе опубликованных за три десятилетия трудов по советской повседневности долгое время был заметен перекос интереса в пользу 1920-х гг. и послевоенных десятилетий [4-7], включение в анализ повседневной жизни 


\section{Социально-экономический и әуманитарный журнал Красноярского ГАУ. 2020. №1}

СССР 1930-х гг. обозначилось несколько позже [8, 9], показав «стремление профессионального сообщества вернуть ранней советской истории статус “нормального” периода нашего прошлого» [10]. Внимание исследователей привлекает в том числе тема организация досуга и отдыха, хотя специальных исследований этой проблемы пока немного [11].

Определенный опыт изучения советской повседневности накоплен и в региональной историографии [12], однако материалы по г. Красноярску 1930-х гг. представлены в основном в обобщающих трудах по истории города [13].

Цель исследования - выявление общих тенденций эволюции культурно-досуговой деятельности населений г. Красноярска в 1930-е гг. и обусловивших их факторов. Задачи исследования: определить ведущие формы досуговой деятельности красноярцев в 1930-е гг. и масштаб охвата ими жителей города.

Свободное время является важнейшим фактором духовного и нравственного развития человека. Величина свободного времени, его структура и содержание являются одной из ключевых составляющих его повседневной жизни, отражающих специфику экономического и социально-политического устройства общества, показателем качества жизни человека. С первых дней существования советское государство с большим вниманием относилось к проблемам свободного времени граждан и стремилось создать такую его структуру, которая в наибольшей степени соответствовала бы формированию «нового человека - строителя социализма». В связи с этим официальные, т. е. организуемые и контролируемые сверху, формы досуга были в значительной степени идеологизированы.

Сразу следует сказать о важном событии, оказавшем влияние на увеличение свободного времени советских граждан в начале 1930-х гг. В феврале 1928 г. на Пленуме ЦК ВКП (б) было принято решение о переходе от восьми- к семичасовому рабочему дню. Перевод красноярских предприятий на новый рабочий день происходил постепенно, как и по всей стране [14].

Безусловно, определенную долю свободного времени в рассматриваемый период занимали мероприятия по ликвидации неграмотности, как особый вид жизнедеятельности, организуемый государством. Однако в городе по-прежнему оставалось большое число неграмотных. К началу 1931 г. неграмотных горожан насчитывалось 1648 человек, а малограмотных - 2486 человек из почти 111-тысячного населения города. Согласно статистике, к концу 1934 г. в городе насчитывалось уже 3357 неграмотных и 5762 малограмотных, в 1937-м - 2500 и 4885 соответственно. Таким образом, количество неграмотных и малограмотных не только не сокращалось, но и увеличивалось за счет притока населения из деревень, где данное явление было повсеместным (общая численность населения Красноярска за 1927-1939 гг. выросла с 72,6 до 190,8 тыс. человек). Однако охват неграмотных различными формами ликбеза постепенно рос - если в 1934 г. только один из девяти негра- 
мотных посещал курсы ликбеза, то в 1937 г. - почти половина [15, с. 161; 13 , с. 400]. Показатель грамотности городского населения Красноярска к 1939 г. хоть и не достиг среднероссийского показателя, но все же достиг впечатляющих 85,9 \%. Рост грамотности горожан, безусловно, способствовал росту их культурных потребностей и изменению структуры досуга.

В 1930-е гг. наблюдалось повышение расходов красноярцев на удовлетворение культурно-просветительских нужд. Этому способствовала постепенная нормализация положения в социальной сфере во второй половине 1930-х гг., рост заработной платы, снижение цен на продукты питания и коммунальные услуги, что высвобождало средства для культурных нужд. На первом месте по затратам здесь находилась молодежь. По данным обследования комсомольцев Красноярска, на посещение зрелищных учреждений они расходовали 7,9 \% зарплаты, на покупку газет и разнообразной литературы - 12,8 \% [1, с. 143-144].

Ежедневное чтение газет становится в 1930-е гг. одним из типичных видов досуга в свободное время. Распространению газет, их внедрению в быт уделялось много внимания партийными, профсоюзными и советскими органами. Подписка на газеты стала неотъемлемой чертой повседневной жизни красноярцев, проходили кампании подписки и пропаганды газет. Так, в 1931 г. в Красноярске, численность населения которого составляла 110,9 тыс. человек, было выписано 84090 экземпляров газет и журналов [16, с. 27]. При этом не стоит забывать, что зачастую людей, находившихся подчас в нужде, принуждали выписывать периодические издания, причем не только коммунистов, но и беспартийных. Помимо подписки горожане покупали газеты и в розничной продаже. В 1930-е гг. были две краевые газеты. Ежедневно, с 1905 г., выходила газета «Красноярский рабочий», тираж которой в 1939 г. составил 65 ооо экземпляров. С 20 января 1935 г. начала издаваться газета «Красноярский комсомолец». Кроме того, в Красноярске выходил ряд ведомственных газет. Всего к 1940 г. у красноярцев была возможность читать более 100 газет общесоюзного и местного характера [14, с. 97].

Начиная с конца 1920-х гг., в быт красноярцев постепенно начинает входить радио, которое становится необходимым каналом получения информации и потребления культуры. Еще в марте 1927 г. в Красноярске была открыта приемная радиостанция, а в ноябре того же года проведена первая красноярская передача. В 1931 г. был создан красноярский радиоузел, поступили в продажу первые радиоприемники. Продолжительность ежедневных эфиров постепенно возросла с 6 до 12 ч. Помимо передач станций Новосибирска, Томска, Иркутска, Москвы, транслировались и местные программы, в том числе с места событий - из клубов, театров, с площадей. Популярность радио стремительно росла - к 1934 г. к радиоцентру было подключено 2700 точек в городе, в многолюдных местах устанавливались громкоговорители для трансляции новостей и концертов. С 22 февраля по 13 марта 1939 г. в Красноярске проходила первая краевая радиолюбительская выставка, которая привлекла внимание всех радиолюбителей. Всего за время функционирования выстав- 


\section{Социально-экономический и әуманитарный журнал Красноярского ГАУ. 2020. №1}

ки ее посетило 9500 человек. Было представлено 35 экспонатов, из них 19 экспонатов - детского творчества [17].

Типичной формой удовлетворения культурных потребностей красноярцев становилось чтение художественной и научно-популярной литературы. В 1920-е гг. личные библиотеки еще не были обычными в жилищах горожан. Но уже в 1930-е гг. спрос на книги возрос, о чем свидетельствует рост книготорговли в целом по Сибири. Распространению книги среди красноярцев также содействовало увеличение числа библиотек и количества книг в их фондах. Уже в 1934 г. в городе работало 89 библиотек всех типов, каждый пятый житель города был читателем библиотеки, 55 \% из них посещали именно массовые библиотеки [18]. В городе функционировала публичная библиотека, которая была основана еще в 1846 г. (ныне Центральная городская библиотека им. М. Горького). В июне 1935 г. на базе книгохранилища краеведческого музея, книжных фондов губернского земельного управления, духовной семинарии, епархиального училища, церковно-учительских курсов и частично Юдинской библиотеки была создана Краевая библиотека им. В.И. Ленина. 25 мая 1936 г. библиотека была открыта для читателей на площади Революции. Это была самая крупная библиотека края, которая на момент открытия имела в своем фонде 30 тыс. книг. Помимо публичных, существовали ведомственные, профсоюзные, учебные и передвижные библиотеки, готовые предоставить свои услуги красноярцам. К концу 1930-х гг. в городе работало уже 111 библиотек, книжный фон которых насчитывал более 825 тыс. книг. Правда, из-за опережающего роста численности жителей города относительная обеспеченность читателей книгами и библиотеками несколько снизилась. Интересы читателей были весьма разнообразными. Большой популярностью пользовалась русская классика: А.С. Пушкин, И.С. Тургенев и другие. Интерес к отечественной классике ярко проявился в 1937 г. во время проведения Пушкинских дней, посвященных столетию со дня гибели поэта. Велик был интерес к произведениям приключенческого жанра, романам Ф. Купера, М. Рида, Ж. Верна. Рабочие проявляли активный интерес и к произведениям советских писателей [1, с. 151]. Читали красноярцы и произведения своих талантливых земляков. В 1936 г. было создано Красноярское книжное издательство, первоначально выпускавшее в год пять-шесть книг. Именно через него получили путевку в жизнь книги И. Рождественского, К. Лисовского, И. Назарова, Н. Устиновича и красноярских писателей. Возрастал интерес к научно-популярной литературе.

Все более популярным становилось посещение музеев. Так, за 1939 г. Краеведческий музей посетило 66719 тыс. человек, можно предположить, что подавляющее большинство из них составили жители собственно Красноярска, численность населения которого к этому времени достигла 190,8 тыс. человек [19].

В формировании структуры свободного времени важное место занимало посещение зрелищных учреждений. Просмотр кинофильма, театрального спектакля и других представлений создавал возможности 
для полноценного отдыха красноярцев во внерабочее время. Формирование привычки у большинства горожан к посещению зрелищных учреждений являлось также эффективным средством вытеснения различных негативных форм проведения досуга.

Расширялась сеть кинотеатров и киноустановок. В довоенные годы в городе функционировали несколько кинотеатров: «Октябрь», «Совкино», «Луч» - в Центральном районе, «Ударник» - в слободе им. III Интернационала. 11 февраля 1939 г. был открыт новый кинотеатр «Железнодорожник» в помещении Дворца культуры, который был рассчитан на 400 мест. Перечисленные кинотеатры были оснащены гардеробами, буфетами, в фойе музицировали джаз-оркестры. Для юных зрителей неподалеку от кинотеатров «Октябрь» и «Совкино» был открыт кинотеатр «Пионер». Правобережье довольствовалось только клубными киноустановками. В газете «Красноярский рабочий» ежедневно публиковалась киноафиша и отзывы о фильмах. На экранах города в эти годы шли такие фильмы, как «Ленин в Октябре», «Возвращение Максима», «Граница на замке», «Богатая невеста» и другие. Особую любовь публики завоевал фильм «Чапаев»: «На улицах города можно было наблюдать, как под красными знаменами под бравурные марши, с усердием исполняемые духовыми оркестрами, на телегах к кинотеатрам города съезжались крестьяне из соседних сел и деревень ...на просмотр одного из первых звуковых фильмов “Чапаев" " [20, с. 236].

Все более распространенной формой досуга становилось посещение театральных спектаклей, цирковых представлений, концертов. Осенью 1934 г. в Красноярске на базе Первого Красноярского советского театра (еще ранее - Пушкинского народного дома-театра) был создан постоянный Краевой драматический театр им. А.С. Пушкина. В нем ставились лучшие пьесы отечественной классики и советских драматургов «Горе от ума», «Борис Годунов», «Волки и овцы», «Васса Железнова», «Мещане», цикл «ленинианы»- «Человек с ружьем», «Кремлевские куранты» и другие. В 1937 г. в городе появился первый театр юного зрителя, который давал свои спектакли во Дворце культуры железнодорожников, но вскоре он прекратил свое существование. В 1938 г. на базе драматического театра был образован кукольный театр. Мы не можем утверждать, что театральные залы были неизменно полные, однако имеющиеся данные свидетельствуют, что за 1940 г. Краевой театр драмы посетило 152,8 тыс. человек (в среднем 426 человек на один спектакль), а представления передвижного театра кукол - 43,4 тыс. зрителей (в среднем 352 человека на один спектакль) - показатели весьма впечатляющие [21].

В Красноярском госцирке, который тогда не имел стационарного здания, часто гастролировали приезжие артисты. Так, например, в январе 1939 г. здесь давал представления знаменитый дрессировщик животных Юрий Дуров. 


\section{Социально-экономический и әуманитарный журнал Красноярского ГАУ. 2020. №1}

В 1938 г. было создано Краевое концертно-эстрадное бюро, организовавшее в Красноярске концерты выдающегося скрипача Д. Ойстраха, джазового оркестра под руководством Д. Покраса и других известных музыкальных коллективов. Его создание, безусловно, способствовало повышению уровня концертных выступлений, но вместе с тем отражало и растущее усиление контроля над зрелищными мероприятиями, которые еще в начале 1930-х гг. вызывали шквал критики у местной прессы. Так, выступления балерины Коралли, сатирика-юмориста Аскольдова и певицы Никандровой в июле 1930 г. в газете «Красноярский рабочий» были названы «пошлостью и обывательщиной» и высказан призыв более тщательно проверять репертуар гастролеров, «положить конец халтуре, смешанной с пошлостями и обывательским подтруниванием над временными трудностями» [22].

В 1930-е гг. возросла роль различных форм активного досуга. Нужно отметить, что красноярцы и, прежде всего, рабочие активно принимали участие в художественной самодеятельности. Значительную роль в структуре досуга красноярцев играли клубы и красные уголки. Особенно велика была эта роль на окраинах города. При клубах действовали различные кружки: художественной самодеятельности, физкультурные, кройки и шитья и т. д. К 1940 г. в городе насчитывалось 11 клубов, 12 красных уголков. Особой популярностью пользовался Клуб железнодорожников им. Карла Либкнехта, любовно называемый красноярцами «Карлушей». В клубе еще с 20-х гг. работало два драматических коллектива - «Синяя блуза» и первый в Сибири «Рабтемаст» (Рабочая театральная мастерская), впоследствии преобразованный в профессиональную труппу, оркестр, радиокружок, собственная библиотека, которая благодаря пущенным по рельсам библиотекам-передвижкам обслуживала читателей с самых дальних станций красноярского участка Транссиба.

В июле 1936 г. в Парке культуры и отдыха им. М. Горького производился набор желающих обучаться западноевропейским танцам: быстрому и медленному фокстроту, бостону, танго и румбе [23]. С середины 1930-х гг. ежегодно проводились смотры художественной самодеятельности. А в феврале 1939 г. в Красноярске проходила Олимпиада самодеятельности, в которой приняли участие многие коллективы рабочих и студентов города.

Общеизвестно, что в 1930-е гг. в организации досуга в CСCP все большее значение приобретали физическая культура, занятия спортом, массовые спортивные игры. Красноярск не был исключением. Физкультурное движение охватывало все более широкие массы. Традицией стало проведение футбольных и волейбольных турниров, кроссов, лыжных вылазок и т. п. Например, в феврале 1931 г. группа красноармейцев с представителями от первого и второго педагогических техникумов предприняли лыжную вылазку из Красноярска в Торгашино с постановкой спектакля. Во второй день мероприятия лыжники разбились на во- 
семь бригад, в состав которых входили колхозники, и провели подворные митинги по вопросам коллективизации и весенней посевной кампании. Вторая половина 1930-х гг. стала временем грандиозных массовых лыжных, пешелыжных и военизированных зимних переходов на значительные расстояния. Так, в феврале 1935 г. состоялся военизированный лыжный переход между населенными пунктами Канск - Красноярск; 18 февраля - 27 апреля 1936 г. - переход Красноярск - Диксон, участниками которого были рабочие Красмашвагонстроя [24, с. 254].

Большое значение в пропаганде физкультуры и спорта имели массовые спортивные праздники, эстафеты, привлекавшие болышое число зрителей. На прошедшем в феврале 1934 г. празднике «бодрости и здоровья» состоялись забеги лыжников на 20, 10, 5 и 3 километра по пересеченной местности, в которых участвовали 83 человека. 12 июля 1936 г. в Красноярске состоялся общегородской парад красоты и здоровья, в котором участвовало около 10 ооо физкультурников.

Наряду с физкультурой и спортом у горожан становились популярными и другие виды активного отдыха. Новым явлением в организации отдыха стало развитие туризма. В 1928 г. в Москве было организовано Общество пролетарского туризма, в городах создавались ячейки Общества, развернувшего работу по организации туризма, вовлечению в свои ряды новых членов. Особенно часто проводились экскурсии на передовые предприятия, в живописные уголки природы и т. п. На март 1931 г. в Красноярске насчитывалось 20 ячеек общества, охватывавших 900 членов [1, с. 177-178].

Были распространены и другие виды активного отдыха, такие как охота, рыболовство, сбор грибов и ягод и т. п. Популярными формами досуга красноярцев являлись отдых на лоне природы, посещение городского сада и парка, экскурсии и массовые выезды за город. Очень популярны были выезды за город коллективом цеха, предприятия. Во время таких выездов устраивались различные подвижные игры, просветительские беседы. Газета «Красноярский рабочий» писала о массовых прогулках железнодорожников, которые сопровождались танцами, играми, хороводами и пением [25].

Одним из любимых мест отдыха красноярцев были «Столбы». К концу 1930-х гг. посещаемость заповедника доходила до 1,5 тыс., а в некоторые выходные дни до 2,5 тыс. человек. «Столбы» приобретали известность далеко за пределами края. Однако часто от посетителей поступали жалобы на плохую организацию отдыха. Отмечалась нехватка избушек, ларьков для туристов. Отсутствовала медицинская служба и средства оказания первой помощи. Не было организовано регулярной переправы. Случайные посетители нередко жгли скамейки, столы или, разводя костры, бросали их не затушенными [26].

Наряду с выездами в пригородную зону горожане отдыхали в черте города. С этой целью улучшалась работа городского сада, оборудовались 


\section{Социально-экономический и әуманитарный журнал Красноярского ГАУ. 2020. №1}

места для отдыха, строились спортивные сооружения. Газета «ВосточноСибирский комсомолец» отмечала, что городской сад Красноярска был признан лучшим в Сибири, но все-таки еще не удовлетворял потребности горожан в культурном отдыхе. Однако с улучшением его работы возрастало число посетителей сада. Так, в 1932 г. в городском саду Красноярска побывало 148215 человек, в 1933 г. - 149823 человека. Летом 1935 г. в Красноярске на территории бывшего городского сада был открыт Городской парк культуры и отдыха им. М. Горького. Он был оснащен читальней, киноустановкой, площадками для игры в крокет, волейбол и теннис, киосками и биллиардной. В парке были введены бесплатные утренние часы, дающие возможность отдыха для взрослых с детьми, пенсионеров и учащихся, особенно во время их весенних зачетов. С 6 часов вечера устраивались платные гулянья, музыка и различные аттракционы местных и заезжих музыкальных, вокальных и сценических трупп [26].

Естественным стремлением человека к контакту с другими людьми являлось общение, которое занимало довольно существенное место в проведении свободного времени в целом. В.И. Исаев, изучив данные обследований, проведенных в 1920-е гг. и в 1936 г., сделал вывод, что на общение с друзьями и родственниками у рабочих затрачивалось 6-7 часов в неделю [1, с. 184].

Таким образом, в структуре свободного времени утверждались новые виды активного досуга, такие как занятия в различных кружках, физкультура, туризм и т. п. Были достигнуты определенные успехи в организации массового отдыха. Однако, наряду с официальными, организованными формами досуга, сохранялись и традиционные: дружеские посиделки, пение частушек, кулачные бои и т. д.

Все же, несмотря на все перечисленные позитивные тенденции, характерные для досуга красноярцев, часто встречались и такие явления, как пьянство и порождаемое им хулиганство. Борьба с пьянством становилась постоянной частью культурно-просветительской работы. В клубах города устраивались «антиалкогольные вечера», лекции, диспуты, показательные суды над пьяницами, продавцами самогона и т. д. Так, Клуб железнодорожников имени К. Либкнехта в 1932 г. организовал демонстрацию протеста против пьянства и пьяниц. Красочно оформленная демонстрация прошла по улицам Красноярска, останавливаясь перед домиками злостных пьяниц для проведения митингов. Настоящей проблемой было хулиганство и драки, которые считались привычным делом. Ударным отрядом в борьбе с хулиганством были рабочие дружины, а также ячейки Общества содействия милиции (Осодмил), на предприятиях города проходили рабочие собрания с участием представителей милиции, на которых обсуждались вопросы наведения порядка в городе.

В целом за годы второй пятилетки уровень хулиганства по сравнению с годами первой пятилетки заметно снизился, хотя и оставался до- 


\section{История}

вольно значительным. В Красноярске, по официальным данным, за вторую половину 1933 г. к ответственности за хулиганство было привлечено 369 человек, за первую половину 1934 г. - 552 человека. Борьбе с хулиганством способствовала деятельность производственно-товарищеских судов на большинстве предприятий. По почину комсомольцев на окраинах города организовывались комсомольские территориальные группы, целью которых были борьба с пьянством и хулиганством. Они проводили специальные собрания, беседы, организовывались вечера, выезды клубов или коллективные посещения культурных учреждений. Такая форма работы давала положительные результаты. Так, в Красноярске 60 бывших хулиганов стали активными участниками общественной работы, 100 человек вступили в комсомол, 20 человек поступили учиться на рабфак и т. д.

На изменение структуры и содержания досуга красноярцев, несомненно, оказывала воздействие и антирелигиозная политика государства, бурный всплеск которой наблюдался в 1930-е гг. Массовое закрытие и уничтожение церквей, разрушение приходской сети города приводило к тому, что верующие теряли возможность, как прежде, посещать храм, уходили в прошлое и крестные ходы, веками являвшиеся необходимым элементом большинства церковных праздников. По указанию партийных органов первичными ячейками и районными оргбюро Союза воинствующих безбожников, комсомольскими организациями, органами народного образования была развернута масштабная антирелигиозная работа - проводились антирелигиозные лекции и выступления на радио на темы «Происхождение христианства», «Происхождение и строение Вселенной и Солнечной системы, развитие жизни на Земле», «Наука и религия», «Происхождение человека», «Война и церковь», «Происхождение и вред Пасхи», «Шпионаж и диверсия под маской религии», демонстрировались кинокартины соответствующей тематики. Все эти меры нанесли огромный удар по традиционной организации религиозной жизни населения, но тем не менее не покончили с религиозностью. В 1939 г. партийные органы власти вынуждены были признать, что религиозная вера продолжает существовать, выражается это в том, что многие по-прежнему отмечали религиозные праздники (особенно Рождество, Пасху и Троицу), исполняли обряды, верили в сверхъестественные силы. Кроме того, распространялось сектантство, которое многим заменяло православную обрядность. Так, рабочие фабрики «Спартак» несколько раз находили баптистские брошюры. В 1939 г. на Красноярском мелькомбинате существовала группа баптистов [27, с. 123, 137].

Подводя итог сказанному, можно сделать вывод, что в 1930-е гг. в структуре свободного времени красноярцев постепенно утверждались новые виды жизнедеятельности. Но следует учитывать, что официальные формы досуга еще не смогли вытеснить традиционные или патриархальные. Оба эти пласта вполне благополучно сосуществовали. Связа- 


\section{Социально-экономический и әуманитарный журрнал Красноярского ГАУ. 2020. №1}

но это было с рядом факторов. Один из них - удаленность Красноярска от центра страны. Периферийное положение приводило к тому, что различные новшества в рассматриваемой сфере если и доходили до города, то с опозданием и в меньшем объеме. Идеологический диктат ощущался меньше, чем в Москве и других крупных городах центра страны. Другим фактором являлся приток сельских жителей в город, которые приносили с собой традиционные формы досуга. Кроме того, сам город в те годы скорее напоминал большую деревню, и широкое распространение традиционных способов проведения свободного времени довольно органично вписывалось в эту картину. Таким образом, главной чертой сферы досуга в рассматриваемый период, на наш взгляд, было гармоничное сосуществование официальных и традиционных форм досуга.

\section{Литература}

1. Исаев В.И. Быт рабочих Сибири. 1926-1937 гг. Новосибирск, 1988.

2. Роль $\oint$ М. Советские массовые праздники / пер. с нем. В.Т. Алтухова; Фонд первого президента России Б.Н. Ельцина. М.: РОССПЭН, 2009.

3. Фицпатрик ШI. Повседневный сталинизм. Социальная история Советской России в 30-е годы: город: пер. с англ. М., 2001.

4. Журавлев С.В., Соколов А.К. Повседневная жизнь советских людей в 1920-е годы // Социальная история. 1997. М., 1998.

5. Лебина Н.Б., Чистиков А.Н. Обыватель и реформы. Картины повседневной жизни горожан в годы нэпа и хрущевского десятилетия. СПб., 2003.

6. Рожков А.Ю. В кругу сверстников: Жизненный мир молодого человека в советской России 1920-х годов: в 2 т. Краснодар, 2002.

7. Зубкова Е.Ю. Послевоенное советское общество: политика и повседневность. 1945-1953. М., 1999.

8. Лебина $H$. Повседневная жизнь советского города: нормы и аномалии. 1920-1930-е годы. СПб., 1999.

9. Андреевский $Г$. Повседневная жизнь Москвы в сталинскую эпоху. 1920-1930-е годы. М.: Молодая гвардия, 2008.

10. Кринко Е.Ф., Тажидинова И.Г., Хлынина Т.П. Повседневный мир советского человека 1920-1940-х гг.: жизнь в условиях социальных трансформаций. Ростов н/Д.: Изд-во ЮНЦ РАН, 2011.

11. Орлов И.Б., Юрчикова Е.В. Массовый туризм в сталинской повседневности. М., 2010.

12. Елизов А.Г. Повседневная жизнь городского населения Красноярского края в середине 1940-х - середине 1960-х гг.: дис. ... канд. ист. наук: 07.00.02 / Иркут. гос. ун-т. Красноярск, 2012.

13. Красноярск: от прошлого к будущему: очерки истории города / ред. кол. Г.Ф. Быконя, В.В. Куимов, П.И. Пимашков [и др.]. Красноярск: PACTP, 2013. 
14. Время - газетной строкой. Красноярск: Кн. изд-во, 1980.

15. Бердников Л.П. Вся красноярская власть: очерки истории местного советского управления и самоуправления (1917-1993 гг.). Факты. События. Люди. Красноярск: Кн. изд-во, 1996.

16. Материалы к отчету горсовета за 1932 г. Красноярск, 1933.

17. ГАКК. Ф.Р-1498. ОП. 2. Д. 33. Л. 7.

18. Сулейманова Ф.Х.С. Библиотечные кадры Красноярского края в 1930-1980-х гг.: состояние, проблемы, динамика // Библиосфера. 2007. № 413 .

19. ГАКК. Ф.Р-13Оо. Оп. 1. Д. 4637. Л. 3.

20.Красноярск. Очерки истории города / сост. П.Н. Мешалкин. Красноярск: Кн. изд-во, 1988.

21. ГАКК. Ф.Р-1300. Оп. 1. Д. 4645. Л. 3.

22. Красноярский рабочий. 1930. 14 июля.

23. Красноярский рабочий. 1936. 3 июля.

24. КПСС в резолюциях и решениях съездов, конференций и пленумов ЦК. М.,1970.

25. Красноярский рабочий. 1935. 6 июня.

26. Красноярский рабочий. 1935. 8 июня.

27. Дворецкая А.П. Религиозная жизнь населения Приенисейского региона в первой трети XX в. (1900-1930-е гг.): монография / А.П. Дворецкая. Красноярск: Изд-во СФУ, 2015.

\section{Literatura}

1. Isaev V.I. Byt rabochih Sibiri. 1926-1937 gg. Novosibirsk, 1988.

2. Rol'f $M$. Sovetskie massovye prazdniki / per. s nem. V.T. Altuhova; Fond pervogo prezidenta Rossii B.N. El'cina. M.: ROSSPJeN, 2009.

3. Ficpatrik Sh. Povsednevnyj stalinizm. Social'naja istorija Sovetskoj Rossii v 30-e gody: gorod: per. s angl. M., 2001.

4. Zhuravlev S.V., Sokolov A.K. Povsednevnaja zhizn' sovetskih ljudej v 1920-e gody // Social'naja istorija. 1997. M., 1998.

5. Lebina N.B., Chistikov A.N. Obyvatel' i reformy. Kartiny povsednevnoj zhizni gorozhan v gody njepa i hrushhevskogo desjatiletija. SPb., 2003.

6. Rozhkov A.Ju. V krugu sverstnikov: Zhiznennyj mir molodogo cheloveka v sovetskoj Rossii 1920-h godov: v 2 t. Krasnodar, 2002.

7. Zubkova E.Ju. Poslevoennoe sovetskoe obshhestvo: politika i povsednevnost'. 1945-1953. M., 1999.

8. Lebina N. Povsednevnaja zhizn' sovetskogo goroda: normy i anomalii. 1920-1930-e gody. SPb., 1999.

9. Andreevskij G. Povsednevnaja zhizn' Moskvy v stalinskuju jepohu. 19201930-e gody. M.: Molodaja gvardija, 2008. 


\section{Социально-экономический и әуманитарный журнал Красноярского ГАУ. 2020. №1}

10. Krinko E.F., Tazhidinova I.G., Hlynina T.P. Povsednevnyj mir sovetskogo cheloveka 1920-1940-h gg.: zhizn' v uslovijah social'nyh transformacij. Rostov n/D.: Izd-vo JuNC RAN, 2011.

11. Orlov I.B., Jurchikova E.V. Massovyj turizm v stalinskoj povsednevnosti. M., 2010.

12. Elizov A.G. Povsednevnaja zhizn' gorodskogo naselenija Krasnojarskogo kraja v seredine 1940-h - seredine 1960-h gg.: dis. ... kand. ist. nauk: 07.00.02 / Irkut. gos. un-t. Krasnojarsk, 2012.

13. Krasnojarsk: ot proshlogo k budushhemu: ocherki istorii goroda / red. kol. G. F. Bykonja, V.V. Kuimov, P.I. Pimashkov [i dr.]. Krasnojarsk: RASTR, 2013.

14. Vremja - gazetnoj strokoj. Krasnojarsk: Kn. izd-vo, 1980.

15. Berdnikov L.P. Vsja krasnojarskaja vlast': ocherki istorii mestnogo sovetskogo upravlenija i samoupravlenija (1917-1993 gg.). Fakty. Sobytija. Ljudi. Krasnojarsk: Kn. izd-vo, 1996.

16. Materialy k otchetu gorsoveta za 1932 g. Krasnojarsk, 1933.

17. GAKK. F.R-1498. Op. 2. D. 33. L. 7.

18. Sulejmanova F.H.S. Bibliotechnye kadry Krasnojarskogo kraja v 19301980-h gg.: sostojanie, problemy, dinamika // Bibliosfera. 2007. № 413.

19. GAKK. F.R-1300. Op. 1. D. 4637. L. 3.

20. Krasnojarsk. Ocherki istorii goroda / sost. P.N. Meshalkin. Krasnojarsk: Kn. izd-vo, 1988.

21. GAKK. F.R-1300. Op. 1. D. 4645. L. 3.

22. Krasnojarskij rabochij. 1930. 14 ijulja.

23. Krasnojarskij rabochij. 1936. 3 ijulja.

24. KPSS v rezoljucijah i reshenijah s'ezdov, konferencij i plenumov CK. M.,1970.

25. Krasnojarskij rabochij. 1935. 6 ijunja.

26. Krasnojarskij rabochij. 1935. 8 ijunja.

27. Dvoreckaja A.P. Religioznaja zhizn' naselenija Prienisejskogo regiona v pervoj treti XX v. (1900-1930-e gg.): monografija / A.P. Dvoreckaja. Krasnojarsk: Izd-vo SFU, 2015.

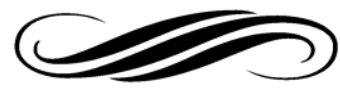

